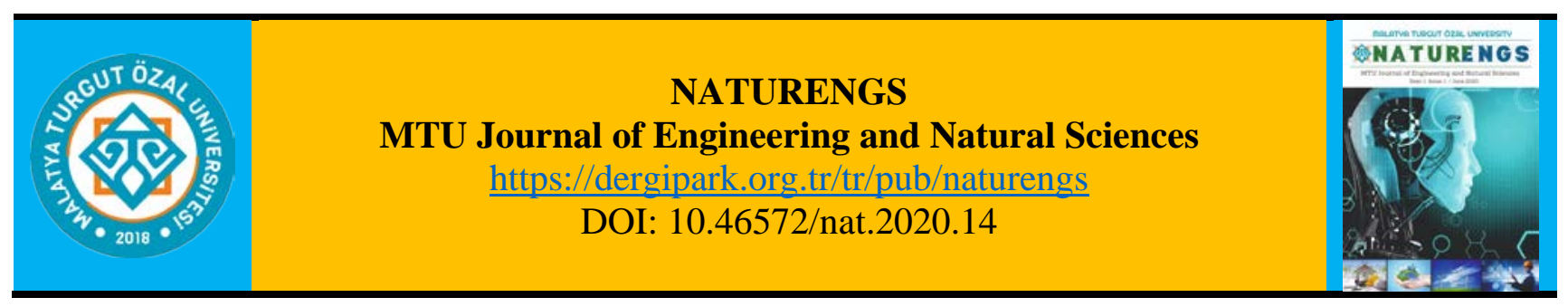

\title{
Low Cost Activated Carbon Synthesis, Characterization and Adsorption Applications
}

\author{
İlhan KÜÇÜK ${ }^{1 *}$, Yunus ÖNAL ${ }^{2}$ \\ ${ }^{1}$ Muş Alparslan University, Muş, Turkey. \\ ${ }^{2}$ Department of Chemical Engineering, Faculty of Engineering, İnönü University, Malatya, Turkey.
}

(Received: 19.11.2020; Accepted: 06.12.2020)

\begin{abstract}
In this study, activated carbon was synthesis from peach kernel shells, which is agricultural waste. The synthesized activated carbons were characterized and their adsorption properties were examined. Activated carbons were synthesized by the physical activation method and $\mathrm{CO}_{2}$ was used as the activation gas. The synthesis was carried out in two steps. In the first step, it was subjected to the carbonization process at 4 different temperatures. During the carbonization process, two different gas flows were used. In the activation process, a temperature of $800^{\circ} \mathrm{C}$ was used. The surface area and morphological properties of the obtained activated carbons were studied by BET, XRD, FTIR and elemental analyzes. Methylene blue was used during adsorption. The adsorption capacities of the samples were calculated.
\end{abstract}

Keywords: Activated carbon, Biomass, Physical activation, Adsorption.

\section{INTRODUCTION}

With the increasing world population, environmental pollution has increased and this has started to affect human health negatively. Increasing pollution has especially polluted our rivers and caused great problems for both human and living life. Especially the drinking water shortage is increasing day by day and urgent measures should be taken. It is important to remove the increasing pollution from nature. Both the efficient materials to be made with these impurities and the use of these materials are important [1,2].

Especially the increasing need for materials used in the adsorption process is increasing day by day. Activated carbon comes first among these materials. The advantages of activated carbons from other materials are that they can be synthesized from waste materials, high surface areas, strong adsorption properties and easy usage. Due to these properties, activated carbon is widely used in adsorption processes [3]. The properties of activated carbons can be synthesized from waste materials, usually by chemical and physical activation. Chemical activation is carried out in two different ways. First, the chemical substance can be applied to the raw material. This activation can be carried out by directly adding chemicals to the raw material. It can also be carried out by adding pure water to the added chemical. This method is called impregnation. Another way of carrying out chemical activation is in two steps. In the first step, carbonization is carried out. Chemical impregnation is applied to the carbonized product. This event is the other type of chemical activation. In physical activation, activated carbon synthesis is carried 
out in two steps. The raw material is carbonized. Activation is applied to the carbonized product. $\mathrm{CO}_{2}$ and water vapor are used for activation. Although the physicochemical activation process has emerged in recent years, it is not a widely used method. What is done in this method is mixing physical and chemical activation [4-6].

Adsorption is the phenomenon of solid, liquid, or gas molecules adhering to a solid surface. This event is to be used excessively, especially in water treatment. The most important pollution in water is the dyestuffs used in textiles, dyeing paper and pulp, plastic, leather, cosmetics, and food industries, and many other areas. Different methods can be used to clean these impurities. Some of these methods are coagulation, reverse osmosis, photodegradation, electrochemical oxidation, ozonation and adsorption. The adsorption method has many advantages compared to other methods. Some of these advantages are low cost, simple installation and ease of application [7, 8].

Methylene blue is the most used basic dye in adsorption studies. Although its use is not very dangerous, it causes vomiting, jaundice, skin diseases and heart diseases in living creatures that are constantly exposed [9].

In this study, activated carbon was synthesis from peach seed shells by physical activation. $\mathrm{CO}_{2}$ was used as gas in physical activation. The reason for using the peach kernel shell is that it has a high carbon content and is abundant in this waste. The reason for using $\mathrm{CO}_{2}$ is that its pore distribution is in a narrow area. Carbonization temperatures of $700{ }^{\circ} \mathrm{C}, 800^{\circ} \mathrm{C}, 900{ }^{\circ} \mathrm{C}$ and 1000 ${ }^{\circ} \mathrm{C}$ were used. $800{ }^{\circ} \mathrm{C}$ was applied as the activation temperature.

\section{MATERIAL AND METHODS}

\subsection{Preparation of Activated Carbons}

Activated carbons, the peach seed shell was synthesized without any pretreatment. Peach kernel shell is primarily subjected to pyrolysis. During the pyrolysis process, peach kernel shells were kept at $700^{\circ} \mathrm{C}, 800^{\circ} \mathrm{C}, 900^{\circ} \mathrm{C}$ and $1000^{\circ} \mathrm{C}$ at $100 \mathrm{ml} / \mathrm{min}$ and $500 \mathrm{ml} / \mathrm{min}$ gas flow for 1 hour at a maximum temperature of $10^{\circ} \mathrm{C} / \mathrm{min}$. The solid sample taken from the oven was placed in the oven for physical activation without any pretreatment. The placed sample was activated at $800^{\circ} \mathrm{C}$ with $\mathrm{CO}_{2}$. The synthesis is completed by keeping the sample at this temperature for 1 hour at a heating rate of $10^{\circ} \mathrm{C} / \mathrm{min}$. As a result of the activation, the activated carbons were ground and ready for the analysis phase.

\subsection{Analyzes}

XRD analysis with Rigaku RadB-DMAX II computer-controlled X-ray diffractometer, SEM images with LECO EVO40 brand device, FTIR analysis with Perkin Elmer 100 device, elemental analysis and percentage values with LECO CHNS 932 elemental analyzer, Surface area of activated carbons $77 \mathrm{~K}$ and at relative pressure (P/Po) between $10^{-6}-1$ and $\mathrm{N}_{2}$ adsorption with Brunauer-Emmett-Teller (BET) Tristar 3000 Micromeritics branded Surface Analyzer.

\subsection{Adsorption Test}

1000 ppm methylene blue stock solution was prepared for the adsorption experiment. The stock solution prepared was diluted 10 times and was prepared for the adsorption process by placing it in $100 \mathrm{ppm}$ and $100 \mathrm{ml}$. 0.1 grams of activated carbon sample was placed in the prepared 
flasks and the adsorption process was started for 24 hours. In this process, the mouths of the erlenmeyer were closed with paraffin. Then the extracted samples were measured with a UVVIS device and the samples were calculated as in Equation 1.

$\mathrm{q}=\frac{\mathrm{C}_{0}-\mathrm{C}_{\mathrm{e}}}{\mathrm{W}} * \mathrm{~V}$

$\mathrm{q}=$ The amount of methylene blue adsorbed,( $\mathrm{mg} / \mathrm{g})$

$\mathrm{C}_{0}=$ Initial concentration of methylene blue, $(\mathrm{mg} / \mathrm{L})$

$\mathrm{C}_{\mathrm{e}}=$ Measured methylene blue concentration, $(\mathrm{mg} / \mathrm{L})$

$\mathrm{w}=$ Activated carbon amount,(mg)

$\mathrm{V}=$ Solution Volume,(L)

\section{RESULTS AND DISCUSSION}

BET, FTIR, XRD and Elemental Analysis were performed on activated carbons synthesized from peach kernel shell. Activated carbon was characterized by the analyzes performed. BET analysis results of activated carbons are shown in Table 1.

Table 1. BET analysis results

\begin{tabular}{|c|c|c|c|c|c|c|c|c|c|}
\cline { 2 - 11 } \multicolumn{1}{c|}{} & \multicolumn{2}{c|}{ Carbonization } & \multicolumn{2}{c|}{$\begin{array}{c}\text { Physical } \\
\text { Activation }\end{array}$} & \multicolumn{1}{c|}{} \\
\hline Codes & $\begin{array}{c}\text { Temperature } \\
{ }^{\circ} \mathrm{C}\end{array}$ & $\begin{array}{c}\text { Gas } \\
\text { Flow } \\
\text { Rate }\end{array}$ & $\begin{array}{c}\text { Temperature } \\
\left(\begin{array}{c}{ }^{\circ} \mathrm{C} / 100 \mathrm{ml} \\
\left.\mathrm{CO}_{2}\right)\end{array}\right.\end{array}$ & $\begin{array}{c}\mathrm{S}_{\mathrm{BET}} \\
\mathrm{m}^{2} / \mathrm{g}\end{array}$ & $\begin{array}{c}\mathrm{S}_{\text {micro }} \\
\mathrm{m}^{2} / \mathrm{g}\end{array}$ & $\begin{array}{c}\mathrm{S}_{\text {mezo }} \\
\mathrm{m}^{2} / \mathrm{g}\end{array}$ & $\begin{array}{c}\mathrm{V}_{\mathrm{T}} \\
\mathrm{cm}^{3} / \mathrm{g}\end{array}$ & $\begin{array}{c}\mathrm{V}_{\text {micro }} \\
\mathrm{cm}^{3} / \mathrm{g}\end{array}$ & $\begin{array}{c}\mathrm{V}_{\text {mezo }} \\
\mathrm{cm}^{3} / \mathrm{g}\end{array}$ \\
\hline AC1 & 700 & 100 & 800 & 351.34 & 351.34 & - & - & 0.18 & - \\
\hline AC2 & 700 & 500 & 800 & 334.55 & 334.55 & - & - & 0.18 & - \\
\hline AC3 & 800 & 100 & 800 & 333.04 & 333.04 & - & - & 0.18 & - \\
\hline AC4 & 800 & 500 & 800 & 347.51 & 347.51 & - & - & 0.18 & - \\
\hline AC5 & 900 & 100 & 800 & 168.39 & 168.39 & - & - & 0.17 & - \\
\hline AC6 & 900 & 500 & 800 & 205.82 & 205.82 & - & - & 0.16 & - \\
\hline AC7 & 1000 & 100 & 800 & 12.06 & 12.06 & - & - & 0.052 & - \\
\hline AC8 & 1000 & 500 & 800 & 2.08 & 2.08 & - & - & 0.05 & - \\
\hline
\end{tabular}

According to the BET analysis results shown in Table 1, the highest surface area belongs to the AC1 sample with 351.34. The lowest surface area belongs to the AC8 sample with 2.08. Increased carbonization temperature harmed the surface area. Also, the increased gas flow caused differences in the surface area. The reason for this can be shown that with the increasing gas flow, more $\mathrm{N}_{2}$ particles touch the sample and the differences in the structure occur. However, this situation does not cause pore formation in the structure. Because the gas cannot fully form the pores during the carbonization process. The pores formed by the activation gas either expand completely or pores that are not fully formed begin to form. When looking at activated carbons synthesized at $700^{\circ} \mathrm{C}$ and $800^{\circ} \mathrm{C}$, there is not much change in surface areas. However, when the temperature increases, there is a decrease in surface areas. The decreasing surface area can be explained as breaking down the pore walls in activated carbon with increasing temperature. Another explanation is that the pore formation in the material may have decreased with increasing temperature. Since activated carbons are produced by the physical 
activation method, $\mathrm{CO}_{2}$ is used as the activating gas. Activation gas did not show mesopore formation in the samples. All of the pores formed in all samples are microporous.

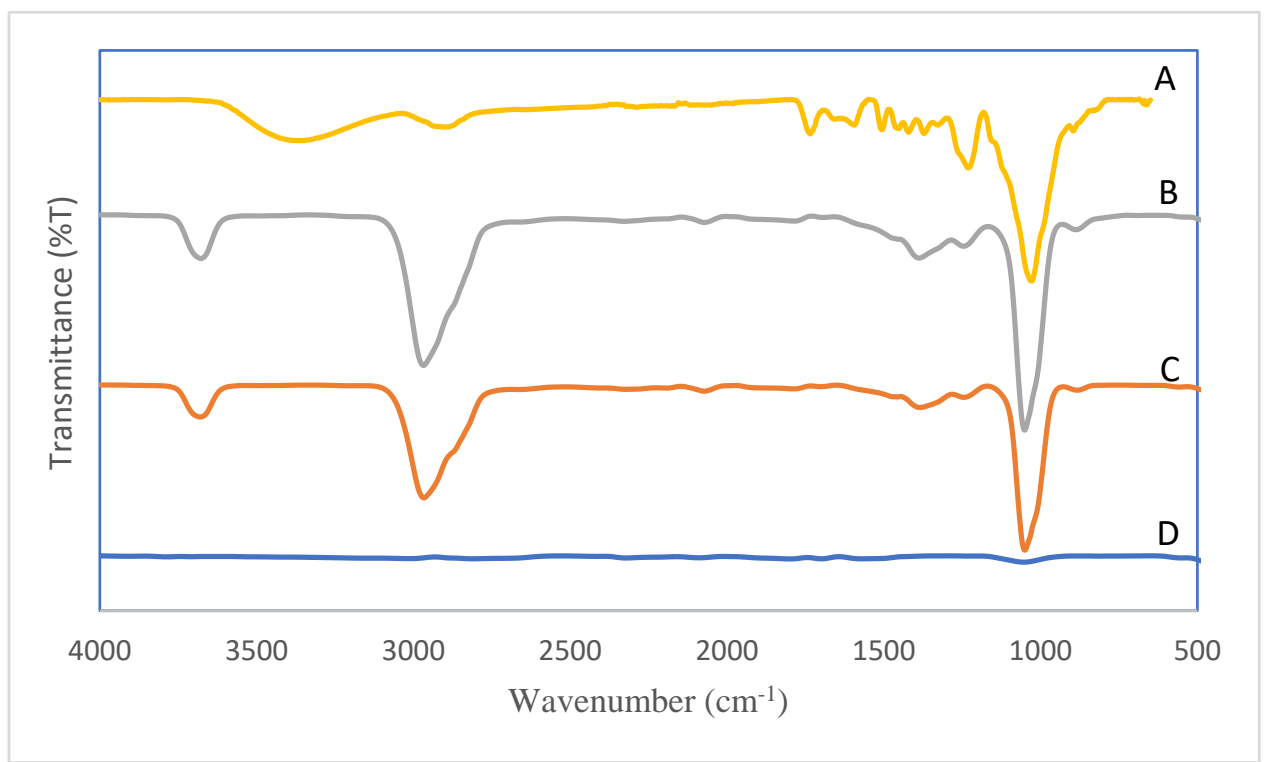

Figure 1. FTIR spectrum A: Raw peach B: AC1 C: AC3 D: AC7

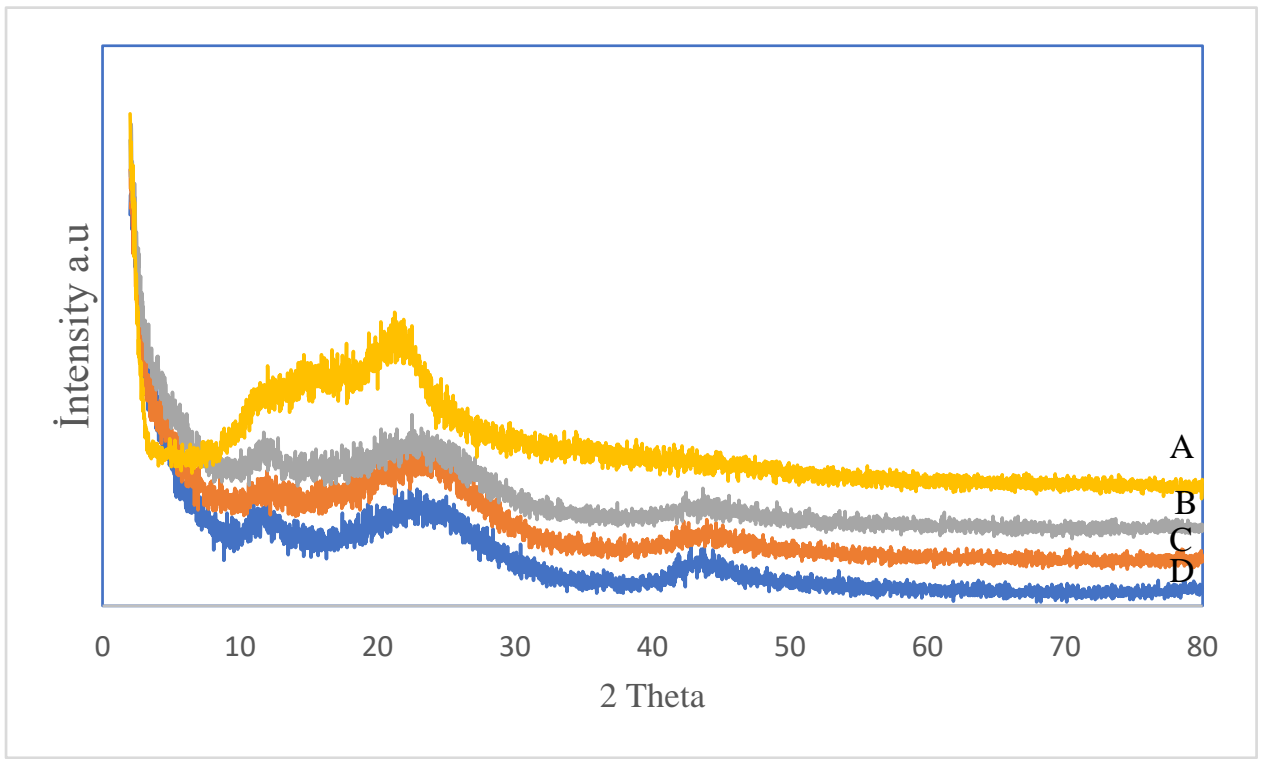

Figure 2. XRD spectrum A: Raw peach B: AC1 C: AC3 D: AC7

FTIR results of some samples are given in Figure 1. According to Figure 1, the peaks existing in the raw peach kernel shell decreased or disappeared in the activated carbon. This phenomenon can be explained by structural changes during carbonization and activation. It is related to the peak-OH stress occurring around $3350 \mathrm{~cm}^{-1}$ in the raw peach peel, and it is proof of the presence of hydroxide molecules in the structure. This may mean the presence of a structure such as phenol or alcohol in the hydroxide molecule structure. In addition, this peak occurred in cellulose in the structure. The peak that occurred around $3050 \mathrm{~cm}^{-1}$ was formed by 
$\mathrm{C}-\mathrm{H}$ bending in the structure. The peak that occurs at about $1700 \mathrm{~cm}^{-1}$ is the peak that occurs from the $\mathrm{C}=\mathrm{O}$ molecule in the structure. The peak that occurs at about 1100 is from the $\mathrm{C}-\mathrm{O}$ molecule. Another characteristic analysis for samples is XRD analysis. XRD analysis is shown in Figure 2. According to XRD analysis, no crystallized regions were found in the raw peach skin. There are 3 different semi-crystalline zones in the structure. The structure is generally amorphous. The flat peak around 22 thetas appears as the cellulose peak and is seen in cellulosecontaining materials. This peak is considerably reduced in activated carbon samples. This means that the cellulose in the structure is broken down.

Table 2. Elemental analysis of some samples

\begin{tabular}{|c|c|c|c|c|c|}
\hline Sample & $\% \mathrm{C}$ & $\% \mathrm{H}$ & $\% N$ & $\% \mathrm{~S}$ & $\% O$ \\
\hline Peach Kernel Shell & 50.45 & 5.683 & 0.072 & - & 43.795 \\
\hline $\begin{array}{c}700^{\circ} \mathrm{C} 100 \mathrm{ml} / \mathrm{min} \mathrm{N}_{2} \\
800^{\circ} \mathrm{C} \mathrm{CO}_{2}\end{array}$ & 51.11 & 0.874 & 0.134 & - & 47.882 \\
\hline $\begin{array}{c}800^{\circ} \mathrm{C} 100 \mathrm{ml} / \mathrm{min} \mathrm{N}_{2} \\
800^{\circ} \mathrm{C} \mathrm{CO}_{2}\end{array}$ & 47.45 & 0.776 & 0.218 & - & 51.556 \\
\hline $\begin{array}{c}1000^{\circ} \mathrm{C} 100 \mathrm{ml} / \mathrm{min} \mathrm{N}_{2} \\
800^{\circ} \mathrm{C} \mathrm{CO}_{2}\end{array}$ & 80.40 & 0.699 & 0.475 & - & 18.426 \\
\hline $\begin{array}{c}1000^{\circ} \mathrm{C} 500 \mathrm{ml} / \mathrm{min} \mathrm{N}_{2} \\
800^{\circ} \mathrm{C} \mathrm{CO}_{2}\end{array}$ & 69.16 & 0.441 & 0.663 & - & 29.736 \\
\hline
\end{tabular}

Some samples were analyzed for elementary analysis. Element analysis results are given in Table 2. According to Table 2, there is approximately 50\% carbon content in the raw peach kernel shell. Increasing carbon content in materials is important for active carbon synthesis. This ratio in peach kernel shell is sufficient for activated carbon synthesis. The carbon content of activated carbons is generally higher than the raw peach kernel shell. This result is generally expected. This is because the shell is subjected to pyrolysis and activation processes. In general, there is a noticeable decrease in the amount of hydrogen. There is an increase in the amount of nitrogen. The occurrence of these differences is a show of change in structure. In addition, the increased amount of carbon according to the element analysis results caused some peaks to expand and decrease in FTIR and XRD analyzes. Approximately $1100 \mathrm{~cm}^{-1}$ peak increase occurring in FTIR consists of C-O stretch and vibration. The increase in this peak and the increase in the $\mathrm{C}-\mathrm{H}$ bending peak at approximately $3050 \mathrm{~cm}^{-1}$ can be explained by the ratio of $\mathrm{C} / \mathrm{H}$ and $\mathrm{C} / \mathrm{O}$. Also, the change in XRD, especially the decrease in the peak of cellulose, is observed. However, the regular regions seen may come from the increased amount of carbon.

Methylene blue adsorption capacitors of activated carbons were studied. Study results are given in Table 2 . The methylene blue adsorption capacity of the activated carbons synthesized according to Table 2 was found to be quite low. The methylene blue molecule is a very large molecule with a molecular structure of $\mathrm{C}_{16} \mathrm{H}_{18} \mathrm{ClN}_{3} \mathrm{~S}$. When looking at the synthesized activated carbons, pores are generally micropores. Micropores are a term used for pores formed at $2 \mathrm{~nm}$ and below. These pores are too low for methylene blue to enter. Therefore, since the methylene blue molecule cannot pass through the pores, it is quite natural that the methylene blue adsorption capacity is quite low. 
Table 3. Methylene Blue adsorption of samples

\begin{tabular}{|c|c|c|c|c|}
\hline \multicolumn{2}{|c|}{ Carbonization } & Physical Activation & \multicolumn{1}{|c|}{} \\
\cline { 1 - 2 } $\begin{array}{c}\text { Temperature } \\
{ }^{\circ} \mathrm{C}\end{array}$ & $\begin{array}{c}\text { Gas Flow } \\
\text { Rate }\end{array}$ & $\begin{array}{c}\text { Temperature } \\
\left({ }^{\circ} \mathrm{C} / 100 \mathrm{ml} \mathrm{CO}_{2}\right)\end{array}$ & $\begin{array}{c}\mathrm{S}_{\text {BET }} \\
\mathrm{m}^{2} / \mathrm{g}\end{array}$ & $\begin{array}{c}\text { Adsorption Capacity } \\
\mathrm{q}_{\mathrm{e}}(\mathrm{mg} / \mathrm{g})\end{array}$ \\
\hline 700 & 100 & 800 & 351.34 & - \\
\hline 700 & 500 & 800 & 334.55 & 1.66 \\
\hline 800 & 100 & 800 & 333.04 & 1.77 \\
\hline 800 & 500 & 800 & 347.51 & - \\
\hline 900 & 100 & 800 & 168.39 & 2.76 \\
\hline 900 & 500 & 800 & 205.82 & 3.67 \\
\hline 1000 & 100 & 800 & 12.06 & 1.66 \\
\hline 1000 & 500 & 800 & 2.08 & 4.44 \\
\hline
\end{tabular}

\section{CONCLUSIONS}

In this study, activated carbon synthesis was prepared from a peach kernel shell. In the synthesis of activated carbon, the surface area was expanded and these results are given by the measurement of the BET device. In the results given, the structure consists entirely of micropores. This means that the pores seen in this structure are quite small. It is seen in the literature that active carbons synthesized by physical activation generally have lower surface areas than those synthesized by chemical activation. In addition to the fact that the surface areas are very small, the rate of micropore is quite high. Water vapor is used in physical activation, which is another study in the literature. By the information given in the literature, the surface area of activated carbons synthesized by water vapor activation is higher than $\mathrm{CO}_{2}$. This phenomenon explains that the $\mathrm{H}_{2} \mathrm{O}$ molecule is smaller than the $\mathrm{CO}_{2}$ molecule. Small molecules enter the pore circles and expand the pores. Therefore, more mesopore is observed in studies used $\mathrm{H}_{2} \mathrm{O}$. In this study, the benefit of the $\mathrm{CO}_{2}$ molecule used in comparison to other activation agents is that it produces a high amount of micropore. In line with these results, if a high amount of micropore is desired in the activated carbon that we will synthesize, $\mathrm{CO}_{2}$ should be used. However, since these activated carbons have low methylene blue adsorption, other application areas can be examined.

With this study, a new type of activated carbon with narrow pore distribution was added to the literature. A narrower pore distribution can be achieved by further expanding the study. Activated carbons which narrow pore distribution can be used as carbon molecular sieves.

\section{Acknowledgment}

This study was supported by the unit of Scientific Researches of Inonu University in Malatya, Turkey; Project no: FDI-2017-680 


\section{REFERENCES}

[1] Türkyılmaz, A. (2018). Sulu Çözeltilerde Nano Kil(Halosit) Yüzeyine Metilen Mavisi Adsorpsiyonu Ve Kinetiği, BAUN Fen Bil. Enst. Dergisi, 20(2): 413-424.

[2] Türkyılmaz, A. ve Işınkaralar, K. (2020). Sulu Çözeltilerden Aktif Karbon Üzerine Adsorpsiyon İle Antibiyotiklerin (Tetrasiklin Ve Penisilin G) Giderimi, Journal of Engineering Sciences and Design, 8(3): 943951.

[3] Uzunoğlu, D., Özer, A. ve Özdemir, Z. (2015). Basıc Red 46 Boyar Maddesinin Montmorillonitli Kireç Taşına Adsorbsiyonu, Anadolu University Journal of Science and Technology A-Applied Sciences and Engineering, 16(2): 303-315.

[4] Erdoğan, F.O. and Kopaç, T. (2020). Investigation of acetone adsorption characteristics of activated carbons obtained from Zonguldak-Karadon coal at room temperature, Journal of the Faculty of Engineering and Architecture of Gazi University, 35(4): 2211-2224.

[5] Ioannidou, O. and Zabaniotou, A. (2005). Agricultural residues as precursors for activatedcarbon productionA review. Renewable and Sustainable Energy Reviews 11: 1966-2005.

[6] Heidarinejad, Z., Dehghani, M.H., Heidari, M., Javedan, G., Ali, I. and Sillanpaa, M. (2020). Methods for preparation and activation of activated carbon: A review, Environmental Chemistry Letters, 18: 393-415.

[7] Ceyhan, A.A. ve Baytar, O. (2018). Metilen Mavisinin Magnetik NiFe2O4/Aktif Carbon Nanokompoziti İle Adsorpsiyonu: Kinetik ve İzoterm, Selcuk Univ. J. Eng. Sci. Tech, 6(2):227-241.

[8] Findık, S. (2020). Congo Red Removal From Aqueous Solutions by Adsorption on Peanut Hull, Müh.Bil.ve Araş. Dergisi, 2(1):28-35.

[9] Polat, İ. ve Orhan, R. (2019). Şeftali Çekirdeği Kabuğu Kullanarak Metilen Mavisi Boyasının Giderilmesi İçin Sabit Yatakl1 Kolonun Adsorpsiyon Performans1, AKU J. Sci. Eng., 19:861-870. 